\title{
Study on the Flood Water Resources and its Utilization in Western Jilin
}

\author{
Xin JIANG ${ }^{1, a}$, Yuyu LIU2, b, and Shan JIANG ${ }^{3, c}$ \\ ${ }^{1}$ Institute of Water and Environmental Research, Faculty of Infrastructure Engineering, Dalian \\ University of Technology, Dalian, 116024, China \\ ${ }^{2}$ Northeast Institute of Geography and Agroecology, Chinese Academy of Sciences, Changchun \\ 130102, China \\ ${ }^{3}$ Shandong Linyi Bureau of Land Resources, Linyi, 276000, China \\ aemail: xinjiang@mail.dlut.edu.cn, bemail: yyliu@mail.dlut.edu.cn, cemail: jiangshan0621@163.com
}

Keywords: floodwater; water resources; utilization; Western Jilin

Abstract: Water is the foundational natural resource and strategic economic resource, which plays an important role in maintaining ecosystem and environment. Considering that the flood water resources are a special form, the floodwater utilization is a special way of surface water resource utilization. Based on the hydrologic data from 1956 to 2010, this paper focuses on the study of flood water resources in the western of Jilin province, including analysis of the surface runoff, assessment of ecological basic flow, flood water resources availability and utilization potential of major rivers. The results show that the amount of flood water resources availability and utilization of Nen River, the second Songhua River and Taoer River is $45.73 \times 10^{8} \mathrm{~m}^{3} / \mathrm{a}, 22.38 \times 10^{8} \mathrm{~m}^{3} / \mathrm{a}$ and $4.09 \times 10^{8} \mathrm{~m}^{3} / \mathrm{a}$ in the period of 1956-2010, respectively. The total amount is richer than the annual mean surface runoff $\left(5.39 \times 10^{8} \mathrm{~m}^{3}\right)$, meaning that flood water reources have a high potential to use. Then, The main characteristics and factors of flood water resources are analyzed in the study area. In additon, this paper presents several approaches for floodwater utilization to provide support for sustainable utilization of water resources in Western Jilin in future.

\section{Introduction}

The flood water is one of the unconventional resources with double properties of harms and benefits [1]. In the context of frequent floods and droughts, the flood water resource utilization is an important measure to ensure water resource security in China. Most studies focused on flood disasters and forecast [2, 3], flood risk and efficiency [4, 5], and floodwater utilization and its assessment [6, 7]. The guidelines of water resources governance had turned from "flood control" to "flood management".

The pass-by water resources are abundant in the western region of Jilin province, however, the utilization of these inflows is low. Flood waters constitute more than 80 percent of annual river flow in each river from June to September. Therefore, the utilization of pass-by water resources and flood waters is an important way to solve the shortage of water resources in Western Jilin. Scientific and reasonable regulating of the floods can supply groundwater and surface water resources, reduce the natural siltation or erosion of rivers and reservoirs, prolong the service life of levees, improve water ecological environment, and increase the overall carrying capacity of regional water resources. Then, flood water resources utilization is imperative and important in Western Jilin.

\section{Study Area and Method}

Western Jilin is located in the southwest of Songnen Plain, in the range of $43^{\circ} 22^{\prime} \mathrm{N}-46^{\circ} 18^{\prime} \mathrm{N}$ and $121^{\circ} 36^{\prime} \mathrm{E}-126^{\circ} 12^{\prime} \mathrm{E}$. The terrain looks like a dustpan with high in the east, south, west and low in the north and middle. Western Jilin covers an area of 55,340 $\mathrm{km}^{2}$ that consists of 11 counties (cities): Baicheng, Zhenlai, Taonan, Tongyu, Daan, Songyuan, Qianguo, Qian'an, Changling, Fuyu and Nong'an (Figure 1)[8]. The climate can be characterized by a transitional zone form half-wet to drought, with an annual average temperature of $5{ }^{\circ} \mathrm{C}$. And the annual average precipitation is about $400 \mathrm{~mm}$. Western Jilin has great natural wetland ecosystem, including Xianghai Wetland, Momoge 
Wetland, Chagan Lake, which can play an important role in preventing desertification, water conservation and climate regulation.

Nenjiang River and Songhua River flow along the east side of Jilin. Meanwhile, Taoer River and Hollin River run through the whole area from west to east and flow into Nenjiang River. Heavy rains often cause flooding in the upstream area called Daxing'anling. The area of the river floodplain is large with wider channel after entering the Songnen Plain. Therefore, the flood duration is long and the utilization of rain-flood resources is abundant. In the background of drought (water shortage) and flood (rainy season) in Western Jilin, the utilization of flood water resources has become potential option, which can regulate economic water consumption and increase the ecological flow, with improving the regional water resources carrying capacity. It is an effective way to solve the shortage of water resource and ecological degradation in Western Jilin.

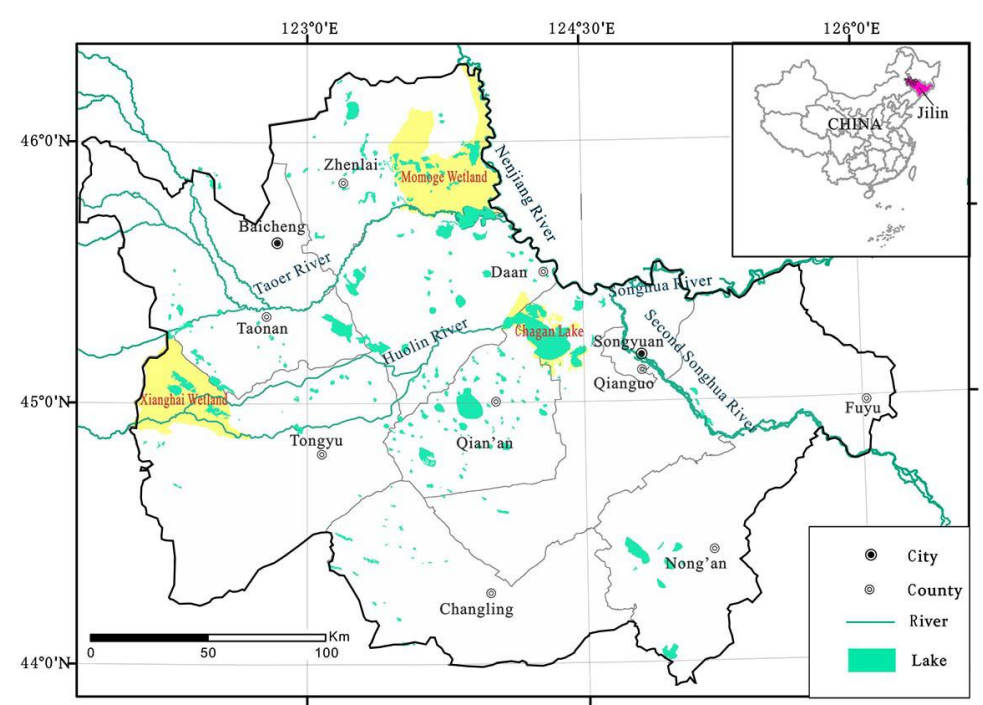

Figure 1 Location of the study area

On the basis of predecessors' research reference, we combine with the actual situation in the study area and the data (main hydrological stations in 1956-2010), and use the comprehensive estimation method to estimate the potential flood water reources for utilization in the main rivers in Western Jilin. The constraint conditions of the comprehensive consideration are: (1) Flood water reources in the study area mainly occurred in rainy season (from June to September), then, the base flow in flood season can be used for calculation; (2) The water requirement in river channel is not lower than the minimum ecological base flow, then, the calculation is based on a safety margin of 1.5 times; (3) When a period of flood runoff is more than the $\eta$ times of the average annual runoff in this period ( $\eta=80 \%$ in the calculation), the excess water amount can be used to estimate the potential flood resources, so as to avoid excessive water consumption in the year of low water and destroy the natural pulsation in river system. The general equation [9] of comprehensive estimation method is:

$Q_{f}(t)=\left\{\begin{array}{cc}Q(t)-\eta \times \overline{Q(t)}, & Q(t)>\eta \times \overline{Q(t)} \\ Q(t)-1.5 Q_{e \min }, & \eta \times \overline{Q(t)}<Q(t)<1.5 Q_{e \min } \\ 0, & Q(t)<1.5 Q_{\text {emin }}\end{array}\right.$

where ${ }^{Q(t)}$ is the observed flow in the western river of Jilin in a certain period; $\overline{Q(t)}$ is the annual mean flow in the period; $Q_{e m i n}$ is the minimum base flow of the control section, which is calculated by the Tennant method [10]. 


\section{Results and Discussions}

\section{Volume of surface runoff}

Surface runoff is the flow of water that occurs when excess storm water, meltwater, or other sources flows over the Earth's surface. Surface runoff flows and stores in rivers, lakes and glaciers from local precipitation, the volume of which is annually dynamic. It represents the natural endowment of local water resources, which is also called surface water resources. The annual mean volume of surface runoff is $5.39 \times 10^{8} \mathrm{~m}^{3}$ in Western Jilin from 1956 to 2010 , included $2.11 \times 10^{8} \mathrm{~m}^{3}$ in Songyuan City and $3.28 \times 10^{8} \mathrm{~m}^{3}$ in Baicheng City, respectively. The variation of surface runoff of Western Jilin is drawn in Figure 2.

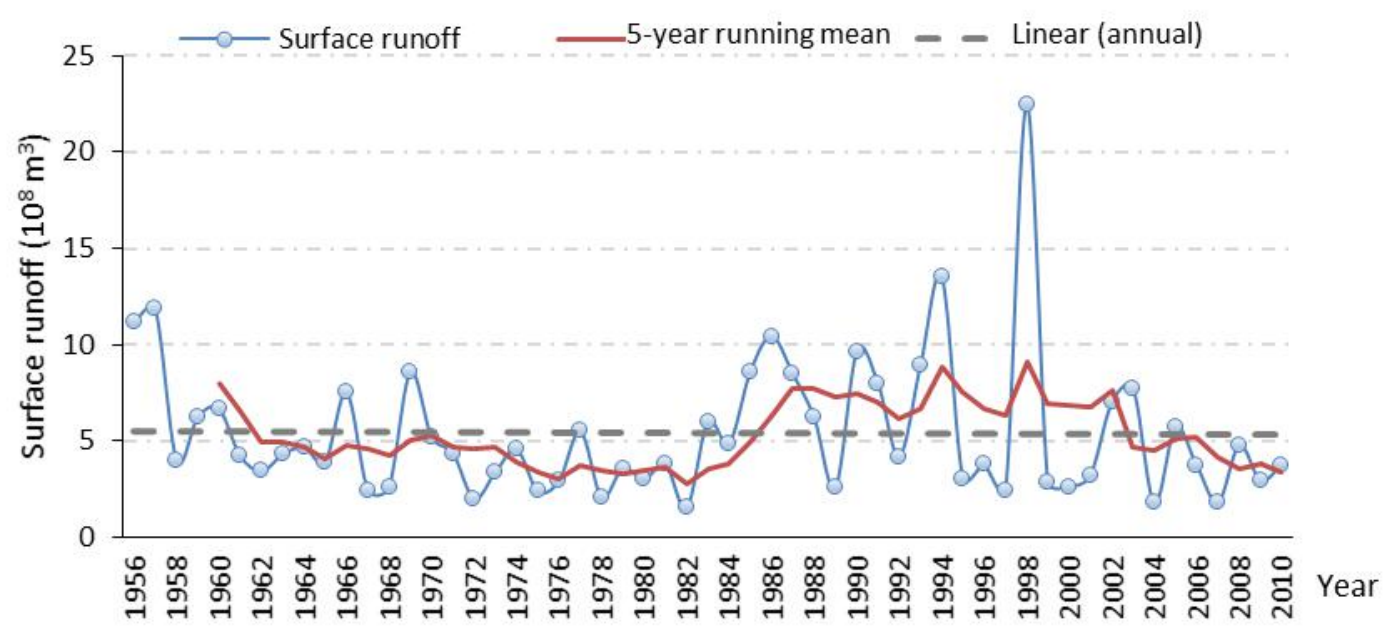

Figure 2 Statistics of the surface runoff in Western Jilin

It shows that there is an obviously fluctuation in the volume of surface runoff in Western Jilin. The maximum appeared in 1998 and the minimum in 1982 , which is $22.49 \times 10^{8} \mathrm{~m}^{3}$ and $1.51 \times 10^{8} \mathrm{~m}^{3}$, respectively. The difference between them is up to about 2.1 billions $\mathrm{m}^{3}$. It trends to firstly decrease from 1956 to 1982, increase from 1983 to 1998, and then decrease from 1999 to 2010.

\section{Potential of flood water resources}

Results of base flow, flood water resources and potential of flood water resources are calculated in Nen River, the Second Songhua River and Taoer River in Western Jilin and shown in Table 1. It did not include the result of Huolin River, because of incomplete data and less runoff compared with others. It shows that the total available flood water resources of Nen River is $45.73 \times 10^{8} \mathrm{~m}^{3} / \mathrm{a}$, about $22.23 \%$ of the annual runoff. The amount of flood water resources in the Second Songhua River and Taoer River are $61.05 \times 10^{8} \mathrm{~m}^{3} / \mathrm{a}$ and $7.75 \times 10^{8} \mathrm{~m}^{3} / \mathrm{a}$, of which the available flood water resources are $22.38 \times 10^{8} \mathrm{~m}^{3} / \mathrm{a}$ and $4.09 \times 10^{8} \mathrm{~m}^{3} / \mathrm{a}$, respectively. The amount of flood water resources in the western region of Jilin is considerable, more than the annual mean volume of surface runoff $\left(5.39 \times 10^{8} \mathrm{~m}^{3}\right)$. 
Table 1 Amount of floodwater resources of major rivers in Western Jilin

\begin{tabular}{|c|c|c|c|c|c|}
\hline \multirow[b]{2}{*}{ Rivers } & \multirow{2}{*}{$\begin{array}{c}\text { Average } \\
\text { annual runoff } \\
\left(10^{8} \mathrm{~m}^{3} / \mathrm{a}\right)\end{array}$} & \multirow{2}{*}{$\begin{array}{c}\text { Ecological base flow } \\
\text { in river channel } \\
\left(10^{8} \mathrm{~m}^{3} / \mathrm{a}\right)\end{array}$} & \multirow{2}{*}{$\begin{array}{c}\text { Amount of flood } \\
\text { water resources } \\
\qquad\left(10^{8} \mathrm{~m}^{3} / \mathrm{a}\right)\end{array}$} & \multicolumn{2}{|c|}{ Potential of flood water resources } \\
\hline & & & & $\begin{array}{l}\text { Total available flood } \\
\text { water } \\
\text { resources }\left(10^{8} \mathrm{~m}^{3} / \mathrm{a}\right)\end{array}$ & $\begin{array}{c}\text { Percentage } \\
\quad / \%\end{array}$ \\
\hline Nen River & 205.75 & 13.54 & 115.05 & 45.73 & 22.23 \\
\hline the Second & & & & & \\
\hline $\begin{array}{c}\text { Songhua } \\
\text { River }\end{array}$ & 146.67 & 7.18 & 61.05 & 22.38 & 15.26 \\
\hline $\begin{array}{l}\text { Taoer } \\
\text { River }\end{array}$ & 11.84 & 0.90 & 7.75 & 4.09 & 34.57 \\
\hline
\end{tabular}

\section{Characteristic of rain-flood resources and its genetic analysis}

For the interannual variability, the availability of flood water resources is a dynamic concept, and its value changes over time. In Figure 3, the histogram describes the flood water resources potential anomaly of major rivers in Western Jilin from 1956 to 2010. It is observed that the flood waters and rainfall are positively correlated, where heavy rainfall is there is rich in flood water resources.

Floods are mainly caused by the short-term heavy rainfall of the flood season in Western Jilin. The characteristics of the flow direction and the water movement are consistent during one year. Generally, rain begins in the upper reaches of Nen River and its western tributary Taoer River in late June. Meanwhile, the flood first occurs in the Taoer River basin. And then, the rainfall is widely seen throughout the entire basin of Nen River in July and August, with the floods gradually shifting eastward and the increasing frequency. Finally, rains and floods are gradually decreasing after September. Therefore, floods account for more than 70 percent of the total in July and August, which mainly produce within 60 days.

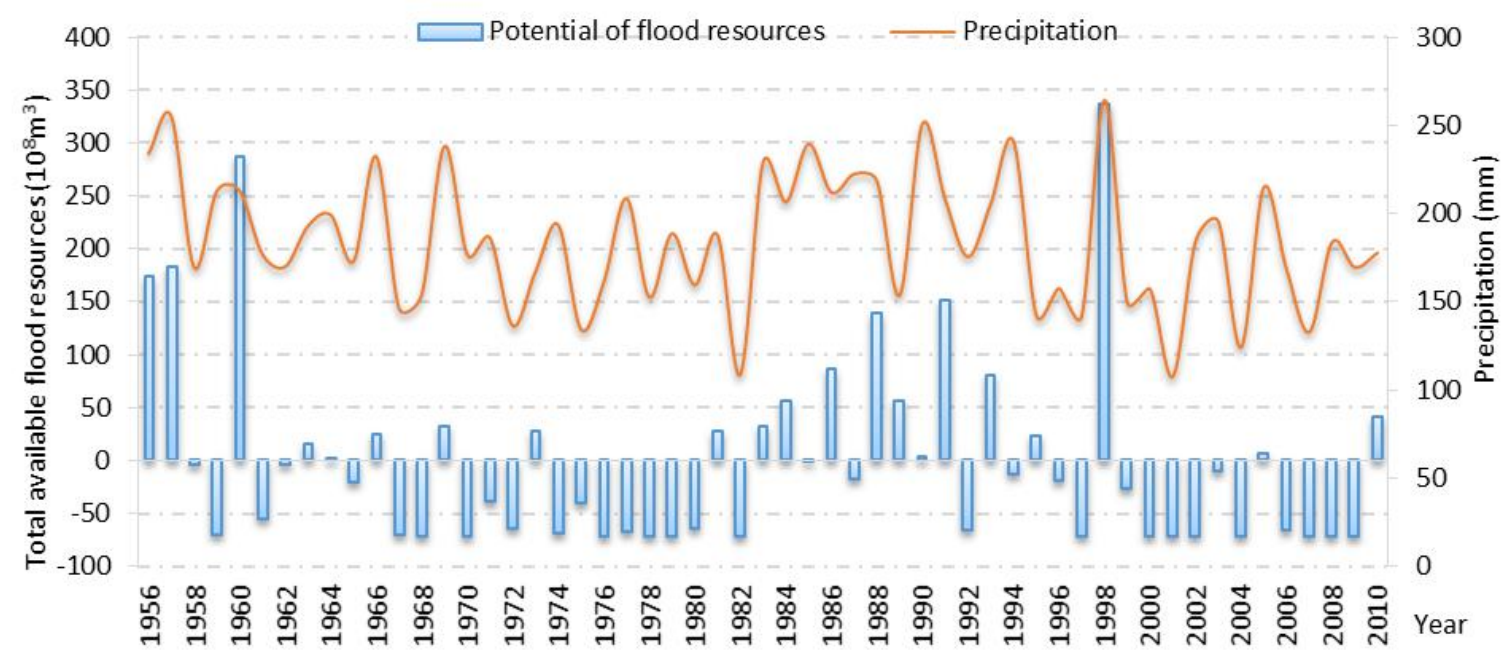

Figure 3 Statistics of the rain flood resources in Western Jilin

Previous researches have shown that the precipitation is the main factor influencing the amount of the flood water resources. While the watershed land use type, underlying surface conditions, vegetation types, the underground water level and the change of human activities can also produce certain influence to regional flood water resources [11]. The land use type has changed a lot in Western Jilin during last decades. Areas of hydrated farmland, dry farmland and saline land increased while grassland, water and wetland decreased. The area of wetland has reduced to $3732 \mathrm{~km}^{2}$ in 2010 , 
which is $57 \%$ of the 1950 s. The flood regulation and storage capacity has reduced due to the change of underlying surface, especially the decreased wetlands. Meanwhile, the water withdrawal of agricultural irrigation has grown greatly, which leads to the decreasing discharge of some rivers and insufficient groundwater recharge. All of these result in dried up rivers, shrunken wetlands and declined groundwater [12]. Furthermore, the eco-hydrological process has changed both locally and regionally in short and long time, which effects on the volume of flood water resources in the study area. In addition, the plain topography makes it in good condition to use flood water resources in Western Jilin. The duration of flood process is long due to the relative broader floodplain, lower gradient and slower confluence [13].

\section{Conclusions}

This paper estimates the flood water resources of major rivers in the western of Jilin province. It shows that the amount of flood water resources availability and utilization potentiality is richer than the annual mean surface runoff. The core content of flood water resources utilization is flood storage and regulation. Considering the actual situation, flood water resources utilization can be realized through the following measures in Western Jilin. More effort should be required to (1) increase reservoirs' capacity, (2)interconnect river system network, (3) build underground reservoirs and (4) recover the floodplain along the rivers, regulate and store the flood water resources.

\section{Acknowledgements}

This research was supported by the Jilin Province Science Foundation for Youths (No. 20160520024JH).

\section{References}

[1] S. G. Xu, J. W. Liu, and B. L. Zhang: Water Power, Vol. 33 (2007), p. 10. (In Chinese)

[2] J.I. Barredo: Natural Hazards and Earth System Sciences, Vol.9 (2009), p. 97

[3] L.M. Braman, M.K. van Aalst, S.J. Mason, P. Suarez, Y. Ait-Chellouche and A. Tall: Disasters, Vol.37 (2013), p. 144

[4] H. Apel, G.T. Aronica, H. Kreibich and A.H Thieken: Natural Hazards, Vol.49 (2009), p. 79

[5] S.B. Lü, S.G. Xu and F. Feng: Natural Hazards and Earth System Sciences, Vol. 12, (2012), p. 341

[6] X. Li, S. Guo, P. Liu and G. Chen: Journal of Hydrology, Vol. 391 (2010), p. 124

[7] D. L. Wang, G.H. Zhang, H.M. Feng, M.J. Yan, Y.L. Tian and J.Z. Wang: Advances in Water Science, Vol. 25 (2014), p. 420(In Chinese)

[8] L. Zhang, G. L. Hou, G. X. Zhang, Z. L. Liu, G. Z. Sun and M. N. Li: Applied Ecology and Environmental Research, Vol.14 (2016), p. 463

[9] J. J. Xu, J. Chen and S. P. Huang: Vol. 40 (2009), p. 474 (In Chinese)

[10]Y. T. Wei, Y. Pang and J. Luo: Journal of Water Resources \& Water Engineering, Vol. 25 (2014), p. 151 (In Chinese)

[11]J. W. Liu, S. G. Xu and S. B. Zhang: Water Resource and Power, Vol. 25 (2008), p. 7 (In Chinese)

[12]L. Q. Dong and G. X. Zhang: Advances in Water Science, Vol. 24 (2013); p. 177 (In Chinese)

[13]Y. N. Wang, M. Chen and Y. Q. Zhang: Vol. 25 (2007); p. 48 (In Chinese) 